\title{
Change and Challenge at UNHCR: A Retrospective of the Past Fifty Years
}

\author{
JENNIFER HyNdMAn
}

\begin{abstract}
The United Nations High Commissioner for Refugees (UNHCR) is arguably the lead un agency in complex humanitarian emergencies. But this is a recent role, whereby UNHCR provides assistance to displaced persons both beyond international borders, in refugee camps, and within conflict zones. The agency has evolved, in practice, beyond its original mandate to protect refugees and ensure solutions to their plight. This short article traces the emergence of UNHCR after World War II in the context of cold war geopolitics and provisions of international law. Specific references are made to the OAU Convention on Refugees and the Cartagena Declaration, both of which shape a specific geography of refugee determination in Africa and the Americas respectively. The paper concludes that with the end of the superpower tensions, humanitarian assistance is being delivered in distinct ways and with new meanings.
\end{abstract}

\section{Résumé}

Le Haut Commissariat des Nations Unies pour les réfugiés (HCR) est sans aucun doute au tout premier rang des agences $d u$ système des Nations Unies impliquées dans des opérations humanitaires d'urgence. Mais c'est là un rôle récent, où la HCR fournit de l'aide à des personnes déplacées à la fois en dehors des frontières internationales, dans des camps de réfugiés et dans des zones de conflit. Ce court article retrace l'évolution du HCR après la deuxième guerre mondiale dans le contexte géopolitique de la guerre froide et les dispositions du droit international. Référence est faite à la Convention de l'OAU sur les réfugiés et à la Déclaration de Carthage, qui toutes deux façonnent la géographie du droit d'asile en Afrique et aux Amériques respectivement. L'article conclut qu'avec la fin des tensions entre super puissances, l'aide humanitaire est maintenant fournie dans des façons bien spécifiques et qu'elle prend de nouvelles formes.
Twenty years ago, the Office of the United Nations High Commissioner for Refugees consisted of some lawyers in Geneva revising and amending the international conventions concerning refugees. Now it is a global rapid-reaction force capable of putting fifty thousand tents into an airfield anywhere within twenty-four hours, or feeding a million refugees in Zaire...

The United Nations has become the West's mercy mission to the flotsam of failed states left behind by the ebb tide of empire.

$$
\begin{array}{r}
\text {-Michael Ignatieff } \\
\text { "Alone with the Secretary General" }
\end{array}
$$

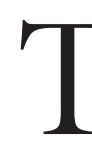

The Office of the United Nations High Commissioner for Refugees (UNHCR) is an expression of the interests of and political conditions in its member states. It has experienced enormous change since its inception after World War II. The transformation is all the more remarkable since the early 1990s, as superpower tensions waned and globalization and economic integration intensified. Tracing the antecedents of this UN agency is important because it elucidates the ways in which it is an expression of particular times and places. Despite being an international organization, UNHCR has been shaped by the contingencies of geography and history.

Winner of the Nobel Peace Prize on two occasions, in 1954 and 1981, UNHCR has a considerable international presence based on its historic role of responding to crises of human displacement. This article briefly traces the historical geography and geopolitical antecedents of the international refugee regime as it emerged after World War II. It provides a context for current debate and discussion about UNHCR operations in a post-cold war and increasingly globalized world. As Michael Barutciski has recently 
commented, "the agency has recently been engaged in activities outside the original mandate that have proven to be complex and problematic when combined with the promotion of asylum." The idea of "principled pragmatism" has emerged from the humanitarian experience of the 1990s, and its core operating guidelines remain uncertain. Just as the terrain of conflict and displacement has changed dramatically over the past fifty years, so too have the operations of UNHCR. Whereas most casualties at the turn of the last century occurred among soldiers at the battle front, civilian deaths and injuries constituted 60 to 80 per cent of casualties at the end of the twentieth century. $^{2}$

Articles 1, 55, and 56 of the United Nations Charter are a framework for the provision of political and legal protection to refugees, displaced persons, and other vulnerable groups, and UNHCR is one of the international organizations charged with this responsibility. ${ }^{3}$ Formally established after World War II in Europe, the Office of the UNHCR was a response to the many displaced and stateless people who required legal protection and material assistance. It replaced the International Refugee Organization (IRO), which had been established immediately after the war. The Office of UNHCR was to complement international law protecting refugees, primarily the 1951 Convention relating to the Status of Refugees. ${ }^{4}$

Despite the fact that 132 states were party to the convention in 2000, it remains explicitly and implicitly Eurocentric. ${ }^{5}$ From its conception, the Convention clearly demarcated geographical and historical limits. It was designed to apply to refugees in Europe displaced by events that occurred prior to 1951. The convention is characterized by its Eurocentric focus and strategic conceptualization. ${ }^{6}$ Its definition of refugee is spatially coded as European. Substantively, its emphasis on persecution based on civil and political status as grounds for refugee status expresses the ideological debates of post-wWII European politics, particularly the perceived threats of Communism and another Holocaust. In emphasizing civil and political rights, the convention minimizes the importance of other human rights. "Unlike the victims of civil and political oppression,... persons denied even such basic rights as food, health care, or education are excluded from the international refugee regime (unless that deprivation stems from civil or political status.)"7 These features of the convention-its European geographical focus and emphasis on civil and political rights-have generated an uneven geography of refugee asylum which, today, is the source of contentious debate.

\section{The Convention mandate includes anyone who}

as a result of events occurring before 1 January 1951 and owing to well-founded fear of being persecuted for reasons of race, religion, nationality, membership of a particular social group or political opinion, is outside the country of his [sic] nationality and is unable or, owing to such fear, is unwilling to avail himself of the protection of that country; or who, not having a nationality and being outside the country of his former habitual residence as a result of such events, is unable or, owing to such fear, is unwilling to return to it. ${ }^{8}$

Despite its definition of refugee, the Convention leaves actual status determination to individual governments. It says virtually nothing about procedure. ${ }^{9}$

The definition implicitly promulgates a hierarchy of rights, giving greater emphasis to political and civil rights of protection than to persecution over economic, cultural, and social rights, and to scales of violence broader than individual persecution. ${ }^{10}$ The definition was also an expression of a particular geopolitics. "The strategic dimension of the definition comes from successful efforts of Western states to give priority in protection matters to persons whose flight was motivated by pro-Western political values." ${ }_{11}$ The Convention definition of refugee was based on an ideologically divided world, grounded in relational identities of East and West. The 1951 Convention was designed to facilitate the sharing of the European refugee burden:

Notwithstanding the vigorous objections of several delegates from developing countries faced with responsibility for their own refugee populations, the Eurocentric goal of the Western states was achieved by limiting the scope of mandatory international protection under the Convention to refugees whose flight was prompted by a pre-1951 event within Europe. While states might opt to extend protection to refugees from other parts of the world, the definition adopted was intended to distribute the European refugee burden without any binding obligation to reciprocate by way of the establishment of rights for, or the provision of assistance to, non-European refugees. ${ }^{12}$

Assistance to non-European refugees was optional. Solutions to the displacement of Europeans after World War II were the focus of the convention.

Complementing this emerging state-based regime of international law, the role of UNHCR is outlined legally in UNHCR's statute. The statute defines UNHCR's mandate as one of protecting refugees, as defined by the Convention, and of seeking permanent solutions for refugees in cooperation with governments through their voluntary repatriation or assimilation within new national communities. 
As well, "the work of the High Commissioner shall be of an entirely non-political character ... " ${ }^{14}$ In contrast to the Convention, the statute emphasizes that the work of the un High Commissioner for Refugees will "relate as a rule, to groups and categories of refugees," not individuals. ${ }^{15}$ From the outset, then, UNHCR faced the practical difficulty of a definition of refugee based on individual determination, yet the statute outlined responsibilities for "groups and categories of refugees." This disjuncture has been identified by international legal scholars, one of whom notes the increasing slippage between UNHCR and state responsibilities:

The disjuncture between the obligations of States and the institutional responsibilities of UNHCR is broadest and most clearly apparent in respect of refugees, other than those with a well-founded fear of persecution or falling within regional arrangements. ${ }^{16}$

(I)t was during this period (the early 1980s) that States' reservations as to a general widening of the 'refugee definition' began to confirm the resulting disjuncture between the functional responsibilities of UNHCR and the legal obligations of States. ${ }^{17}$

The vehicle used to bridge the discrepancy between the statute and the Convention mandates was the "good offices" of UNHCR, ${ }^{18}$ first employed in assisting people fleeing the People's Republic of China to Hong Kong in 1957 and then made applicable to all potential displacement not envisaged at the time that the original mandate was established. UNHCR's "good offices" were created by Resolution 1673 (XVI) of the UN General Assembly on December 18,1961 . The resolution provided a basis for action, which aimed to be flexible, responsive, and meaningful in emerging refugee situations, and allowed the High Commissioner to define groups as prima facie refugees without normal determinations procedures. ${ }^{19}$ Prima facie refugees were to a new category of displaced person that was subordinate to the Convention definition and more likely applicable to crises outside of Europe.

Historian Louise Holborn describes the deployment of UNHCR's "good offices" in Africa as a just-in-time measure, qualified by three observations: (1) the "good offices" would provide material assistance only; legal protection was not provided; (2) UNHCR considered refugees on this continent too numerous, dispersed, and poor to make individual assessments necessary for Convention refugee designation; (3) Europeans considered it too difficult to establish that there was a well-founded fear of persecution in Africa, compared to Europe. ${ }^{20}$ Many of these qualifications are, of course, Eurocentric and
Orientalist constructions of African people and point to the hierarchy of cultures and continents at the time. The drawback of the "good offices" provision of material assistance is that it can occur only where and for as long as governments invite UNHCR to assist. ${ }^{21}$ As well, it may be argued that, because of the poverty of many African countries, the material needs of refugees have been provided for at the expense of legal status and protection. ${ }^{22}$

This institutional framework speaks from and to a period when African states were beginning to advocate for and gain independence. It created the basis for a hierarchy of refugee definitions later in the century. The Convention amplified the legitimacy of asylum from persecution that was the result of Nazism and Communism:

$[\mathrm{T}]$ he definition of the term 'refugee' ... was based on the assumption of a divided world ... The problem of refugees could not be considered in the abstract, but on the contrary, must be considered in light of historical facts. In laying down the definition of the term 'refugee', account had hitherto always been taken of the fact that the refugees involved had always been from a certain part of the world; thus, such a definition was based on historical facts. Any attempt to impart a universal character to the text would be tantamount to making it an 'Open Sesame."' ${ }^{23}$

Despite claims to the contrary, the Convention definition was never intended to be universal. The geographically exclusive definition of refugee underplayed violence and material deprivation that was the result of colonialism and imperialism. Only discretionary, ad hoc efforts on the part of UNHCR's good offices were employed to fill the space that geographical and historical differences generated.

The 1967 Protocol relating to the Status of Refugees amended the 1951 Convention. While it rescinded the spatial and temporal restrictions of the Convention by lifting the European-centred, pre-1951 stipulations, it merely created equal access for all member nations to a legal instrument that remained substantively Eurocentric. Emphasis on the abrogation of individual civil and political rights, based on the outcomes of the Second World War, remains central to the Convention definition of refugee that is employed today. Technically, the 1967 Protocol made the definition geographically inclusive, yet the imagined geopolitical landscape on which the premises of asylum were founded remained geographically exclusive and Eurocentric. ${ }^{24}$

A diminishing proportion of refugees meet the formal Eurocentric post-World War II requirements. The legacy 
of this discrepancy between Convention and "other" refugees is a distinctly unequal system of refugee protection and assistance. Hannah Arendt warns that universal rights fall prey to such divides and that the protection of citizens is imperilled in the absence of a nation state: "The danger is that a global, universally interrelated civilization may produce barbarians from its own midst by forcing millions of people into conditions which, despite all appearances, are the conditions of savages." ${ }^{25}$ Arendt, writing during the aftermath of the Second World War, maintains that the rights of citizens as nationals are far more important that those accorded as human rights on a global scale, precisely because they are applicable and enforceable. The Convention definition is decreasingly applicable to the majority of refugees today who face violence on a broader scale and for reasons different from those of post-wWII Europe. For no legal reason, political and civil rights have been underscored at the expense of economic, social, and cultural rights: "those impacted by national calamities, weak economies, civil unrest, war and even generalized failure to adhere to basic standards of human rights are not, therefore, entitled to refugee status on that basis alone." ${ }^{26}$ The definition continues to emphasize the importance of civil and political rights based on "fear of persecution" - a concept based on ideological divisions of East and West in Europe, far more than the material, social, and political conditions in other regions.

\section{Geographies of Asylum: Regional Instruments in Africa and the Americas}

In Africa, the perceived inadequacy of this pair of legal instruments resulted in the drafting of a legally binding regional policy by the Organization for African Unity (OAU). The 1969 OAU Convention Governing the Specific Aspects of Refugee Problems in Africa not only broadened but also reformulated the definition of refugee. It included the 1951 Convention definition, but added the provision that

the term refugee shall also apply to every person who, owing to external aggression, occupation, foreign domination or events seriously disturbing public order in either part or the whole of his [sic] country or origin or nationality, is compelled to leave his place of habitual residence in order to seek refuge in another place outside his country of origin or nationality (Article 1.2).

The oAu definition thus incorporated generalized violence associated with colonialism and other kinds of aggression, including flight resulting from the serious disruption of public order "in either part or the whole" in one's country of origin, as grounds for seeking asylum. ${ }^{27}$ James Hathaway explains the significance of this codification in the OAU convention; his inherently geographical analysis is worth citing at length:

This ... represents a departure from past practice in which it was generally assumed that a person compelled to flight should make reasonable efforts to seek protection within a safe part of her own country (if one exists) before looking for refuge abroad. There are at least three reasons why this shift is contextually sensible. First, issues of distance or the unavailability of escape routes may foreclose travel to a safe region of the refugee's own state. Underdeveloped infrastructure and inadequate personal financial resources may reinforce the choice of a more easily reachable foreign destination. Second, the political instability of many developing states may mean that what is a "safe" region today may be dangerous tomorrow ... Finally, the artificiality of the colonially imposed boundaries in Africa has frequently meant that kinship and other natural ties stretch across national frontiers. Hence, persons in danger may see the natural safe haven to be with family or members of their own ethnic group in an adjacent state..$^{28}$

The OAU definition translated the core meaning of refugee status to the economic and geopolitical realities of the Third World. The definition also recognized in law the concept of group disenfranchisement and the legitimacy of flight where there was generalized danger, not limited to individual persecution.

In 1984, the Cartagena Declaration on Refugees was adopted by ten Latin American states. Written to address the forced migration of people fleeing generalized violence and oppression in Central America, it, too, represents a regional approach to recognizing and improving upon the inadequacy of the Convention definition. The definition derived from the Cartagena Declaration goes further than that of the Convention to include claims based on internal conflicts and massive violations of human rights, and the idea of group designation of refugee. It does not extend as far as the OAU Convention, however, to protect people fleeing disturbances of public order that affect only one part of a given country. While the oAU Convention is legally binding, the Cartagena Declaration-on which the Organization of American States (OAs) definition is based-is not. ${ }^{29}$

The establishment of regional instruments points to an uneven geography of refugee definitions in international law. The Convention and Protocol definition speaks to the experience and prevailing conflict in Europe after wwII. The oAu Convention broke new ground by extending refugee status to groups affected by less dis- 
criminate violence and public disorder in Africa. While not legally binding on member states, the Cartagena Declaration addressed the distinct regional politics and related human displacement in Central America. On a more modest scale, the Council of Europe has also extended its definition to include de facto refugees, that is, "persons who either have not been formally recognized as Convention refugees (although they meet the Convention's criteria) or who are 'unable or unwilling for ... other valid reasons to return to their countries of origin.". ${ }^{\circ}$ The 1951 Convention and 1967 Protocol, together with these regional instruments, constitute the major bases of refugee protection in international law. ${ }^{31}$

Nonetheless, a sizeable class of refugees remains outside the scope of this legal codification. While most of these refugees are recognized as having legitimate need for protection, legal scholars have generated considerable debate over whether this international practice of granting protection has become part of customary international law or is simply an institutional practice of UNHCR that is not binding on states. The politics and funding of humanitarian activities provide the most compelling evidence that protection and assistance afforded those who fall outside the scope of international law are institutional and not part of customary law. "Developing states have conditioned their willingness to protect humanitarian refugees on the agreement of the international community to underwrite the costs of temporary asylum and to relocate the refugees to states of permanent resettlement." ${ }_{32}$ The refugee crisis in Central Africa in 1996 provides a clear example: the Zairian government would not tolerate Rwandan refugees unless the UNHCR and its First World donors were willing to pay for their support..$^{33}$

To illustrate the regional geography of refugee determination in Africa, it is useful to distinguish between de jure and de facto status, and between prima facie and mandate refugees. ${ }^{34}$ There is no definitive application of these terms. They depend on the laws of individual countries, which countries are signatories to what conventions, and the policies of host government towards refugees. De jure refugees are those who are defined as refugees in law, either at national or international levels. National laws vary enormously: in some cases, countries may have no definition of refugees; in others, definitions may be wider than those outlined in the Convention. If there is no national legislation, but a country is party to the 1951 Convention and the 1969 OAU Convention, as in the case of Kenya, for example, refugees in the campsdesignated as prima facie-are also de jure because they are recognized on the basis of the 1969 OAU Convention in international law. De facto refugees are those "who are unable or unwilling to obtain recognition of convention status, or who are unable or unwilling for valid reasons to return to their country of origin." ${ }^{35}$ The term technically refers to people who have some kind of need for protection but do not strictly meet the eligibility criteria. De facto status can usually be withdrawn because it has no legal significance.

Mandate refugees are arguably de jure. They have their legal background in the UNHCR statute, which is not a legally binding instrument, but many legal experts argue that international customary law has developed to give UNHCR mandate refugees legal significance..$^{36}$ Others are of the opinion that this is not so, and that mandate refugees are de facto. In the case of de facto refugees, status is subject to change and interpretation at levels of national and international law. Prima facie refugees are defined in law by the OAU Convention, but may not be recognized as such by individual host states, such as Kenya, despite being signatories to this convention.

UNHCR is often called upon to determine status as well as to protect and assist refugees who do not meet Convention or regional definitions. In Kenya, few are designated "mandate" refugees; most are prima facie refugees. Mandate refugees are assessed individually and are granted temporary protection by UNHCR. Prima facie designation is usually made on a group basis. Individual assessment is the norm for determining Convention status. Outside of the provisions of some international refugee laws but not others, these displaced people can claim some support from UNHCR in terms of material assistance and legal protection. Somali refugees in Kenya have prima facie status because they are in an African country that is a signatory to the OAU Convention. As a "regional" class of refugees, however, they have no special claim to protection under the laws of the 1951 Convention and 1967 Protocol.

As the preceding discussion suggests, there are several instruments, laws, statutes, and bodies applicable to displaced persons in an international context. It is important to distinguish humanitarian law from refugee law and human rights instruments. Humanitarian law consists of the four Geneva Conventions of 1949 and the two additional Protocols of 1977 and is applicable to civilians within their own country during conflict. While humanitarian law codifies standards of conduct during war, which includes protection for internally displaced people, "this provision applies only to persons displaced because 
of armed conflict ... It does not cover inter-communal violence or other cases of internal disturbances that create internal displacement." ${ }_{37}$ The existing law is currently under review precisely because it speaks to conditions of internal displacement in another time and place, rather than to the bases of conflict in African locations. International refugee law mainly comprises the 1951 Convention, the 1967 Protocol, and the 1969 OAU Convention in Africa. It institutionalizes and enforces the UN Declaration of Human Rights, which declares that a person has "the right to leave," and return, to her or his own country, and "the right to seek asylum." ${ }^{38}$ Humanitarian and refugee law draw a clear distinction between the rights and entitlements of internally displaced persons (IDPs) and refugees. These categories are, however, being challenged because only marginal differences in time and space may distinguish an IDP from a refugee. Some policy-makers maintain that refugees and IDPs are often qualitatively part of the same group, divided artificially by a political border. ${ }^{39}$ The question of whether IDPs should be included or excluded from an operational definition of refugee remains an issue of contentious debate. In practice, however, IDPs have been the focus of humanitarian assistance throughout the 1990s, in places like Iraq, Bosnia-Herzegovina, Sri Lanka, and Somalia.

\section{Stating Human Displacement}

Containment and exclusion have been themes in migration for some. Aristide Zolberg organizes economic and political migrations into three epochs: the first spans the sixteenth to eighteenth centuries in Europe; the debut of the second corresponds to the industrial, democratic, and demographic revolutions of the late eighteenth century; and the last begins in the final decades of the nineteenth century. "The emergence of powerful European states in the 15 th century inaugurated a distinctive era in the history of human migrations: the conquest by the Europeans of the New World." ${ }^{\circ}$ While the French Huguenots are generally considered the first group of modern refugees, legal formulations of refugee status are a product of more recent Western history. "Prior to this century there was little concern about the precise definition of a refugee, since most of those who chose not to move to the 'New World' were readily received by rulers in Europe and elsewhere ... This freedom of international movement accorded to persons broadly defined as refugees was adversely impacted by the adoption of instrumentalist immigration policies in Western states during the early twentieth century." ${ }^{11}$ This final period, Zolberg notes, has been marked by the development of a gap between a small number of wealthy, technologically advanced, and militarily powerful countries, and a larger number of poorer states. As well, improved communication has rendered information about world conditions more available, and human mobility has increased as transportation technology improves. According to Zolberg, this enhanced mobility has given rise to perceived threats of invasion by the multitudes of poor strangers, providing a strong impetus for exclusionary measures and strict border controls. ${ }^{42}$

Despite regional conventions and international protocols to protect refugees, the nation state is the main unit of international law and the primary site of enforcement in relation to regional and international agreements, and civilian protection. Louise Holborn notes that "states are the subjects of international law; individuals are only its objects." ${ }^{43}$ At the end of European empire-building and the cold war, the fragmentation of some states has occurred at the same time that economic and political integration - in the form of regional blocs - have progressed. The porosity of borders is historically and geographically contingent: "The reaction among the receiving nations of the North . . . has been . . . to attempt to contain or 'regionalize' refugee problems; that is, to keep those in need of protection and solutions with their regions of origin." 44

The modern institution of asylum is rooted in political geographies of displaced populations during wwII. Denial of asylum, and strategies to contain forced migrants, were part of this institution. Camps were the rule, not the exception, for dislocated groups in Europe: "if the Nazis put a person in a concentration camp and if he made a successful escape, say, to Holland, the Dutch would put him in an internment camp ... under the pretext of national security." 45 Arendt unwittingly anticipates the unequal outcomes of refugee law.

The stateless person, without right to residence and without the right to work, had of course to transgress the law ... $[\mathrm{N}]$ either physical safety-being fed by some state or private welfare agency-nor freedom of opinion changes in the least their [refugees'] fundamental situation of rightlessness. ${ }^{46}$

Arendt's clairvoyant reasoning points to some of the problems and dilemmas of humanitarian assistance in the international refugee regime today. Most refugees in camps today are prohibited from seeking employment or establishing livelihoods independent of the international assistance provided in camps. 
The mobility of refugees and displaced persons remains constrained by borders of the nation state. By definition, asylum requires an international border crossing. If successful in their crossing, refugees become wards of an international refugee regime that relies on the endorsement and financial support of individual nation states. The end of the cold war affected the aid regime by eliminating the rationale for development assistance, but it also coincided with neo-liberal measures of fiscal austerity in many of the donor countries. ${ }^{47}$ The inverse relation between funding development and funding humanitarian emergencies during the 1990 s is interesting. "[I]nternational relief aid for regions in conflict increased fivefold during the 1990s, to a high of $\$ 5$ billion a year. At the same time, long-term development aid dropped overall." ${ }^{48}$ There has been a marked increase in funding for "complex humanitarian emergencies," in which governments voluntarily fund organizations operating at a global level to manage human crises as they arise. ${ }^{49}$ This shift marks a transformation from long-term to short-term funding patterns, and from bilateral aid to multilateral assistance. In short, states are exerting their influence on international affairs by different means. And UNHCR's actions are one expression of these means.

\section{UNHCR Then and Now}

The UNHCR operates today on a scale unimaginable at its conception. Its initial temporary mandate of three years, 1951-4, has been extended repeatedly at five-year intervals since that time. UNHCR tripled its staff numbers since the 1980 s, from 2000 to 6000 at its peak in the 1990 s. $^{50}$ Annual expenditures of Us $\$ 8$ million in 1970 increased to almost us $\$ 1,167$ million in 1994, signalling intense growth, much of which has occurred since the cold war. ${ }^{51}$ In its 2001 budget, UNHCR requested Us $\$ 954$ million for operating expenses. ${ }^{52}$ Displacement in the post-cold war period has contributed to this transformation. The Office of United Nations High Commissioner for Refugees continues to manage crises using the protocol and practices of the international refugee regime as it emerged after the Second World War. Western governments demonstrate remarkable generosity in funding UNHCR's efforts, as well as those of its un counterparts.

Increasingly, however, UNHCR is faced with economic and political pressures to reformulate its terms of reference and operational mandate. "UNHCR's dramatic expansion since it has re-oriented its activities partly reflects the reluctance of donors to have their own asylum policies scrutinized at a time when they are engaged in re- strictive asylum practices." ${ }_{53}$ The distinctive geopolitical landscape of the post-cold war period, combined with the rise of fiscal restraint as the mainstay of economic policy in many industrialized nations, signals shifts within UNHCR as an organization and within the internationally funded realm of humanitarian assistance more generally. UNHCR is funded primarily through voluntary contributions from donor governments, so its actions are shaped by the direction and amount of these funds. To blame UNHCR for all the shortcomings of humanitarian assistance in the 1990 os would be inaccurate. Donor governments play a major role in determining who will be assisted when and where. The extremely uneven geography of international humanitarian assistance in Africa throughout the 1990s (from Somalia to Rwanda, in particular) attests to the whimsy and politics of international response. While the tenth anniversary of the Gulf War reminds governments that international conflict has not disappeared altogether, the vast majority of conflicts that generate displacement today are civil or internal. 54 "Principled pragmatism" may be the order of the day in the realm of humanitarian assistance, but its meaning and implications for asylum remain unclear.

\section{Acknowledgement}

The author would like to thank Bo Viktor Nylund and an anonymous reviewer for their helpful comments on an early draft of this paper.

\section{Notes}

1. M. Barutciski, "Confusion about UNHCR's Role," UNHCR and International Refugee Protection, by D. McNamara and G. Goodwin-Gill (Refugee Studies Programme Working Paper No. 2, June 1999), 2.

2. J. Boutwell and M. T. Klare. "A Scourge of Small Arms," Scientific American (June 2000): 47-55.

3. Francis M. Deng, "The International Protection of the Internally Displaced," International Journal of Refugee Law (summer 1995): 74-86.

4. Dennis McNamara notes that UNHCR does have a supervisory role under Article 35 of the Convention Relating to the Status of Refugees. See D. McNamara, "Opening Address," in UNHCR and International Refugee Protection, 6.

5. us Committee for Refugees, World Refugee Survey, 2000 (Washington, DC: Immigration and Refugee Service of America, 2000), 9. Note that four more states are signatories to only the 1967 Protocol relating to the Status of Refugees, including the us, Venezuela, Swaziland, and Cape Verde.

6. James C. Hathaway, The Law of Refugee Status (Markham/ Vancouver: Butterworths, 1991).

7. Ibid., 8.

8. The Convention entered into force April 22, 1954; this excerpt is taken from note 27 , Article $1(\mathrm{~A})(1)$, cited in Hathaway, "The 
Law of Refugee Status," 6.

9. McNamara, "Opening Address," 8.

10. Fifteen years later, in 1966, two legally binding human rights instruments were created to protect civil and political rights on the one hand, and on the other, economic, social, and cultural rights. The International Covenant on Civil and Political Rights most closely expresses the emphasis of the Convention. It ensures respect for citizens, regardless of language, religion, sex, political opinion, etc., as well as "the right to liberty of movement and freedom"; The State of the World's Refugees: The Challenge of Protection (Toronto: Penguin, 1993), 164. The Covenant on Economic, Social, and Cultural Rights includes provisions that are more applicable to the socalled developing world than to Western countries, such as the right to food, shelter, and basic medical and educational services. While the first covenant applies to individuals, the second refers to particular groups of people.

11. Hathaway, "The Law of Refugee Status," 6.

12. Ibid., 9 .

13. Article 2 of The Statute of the Office of the United Nations High Commissioner for Refugees (1950) in UNHCR, 1993, op. cit., 162.

14. Article 2 of The Statute of the Office of the United Nations High Commissioner for Refugees (1950) in UNHCR, 1993, op. cit., 162.

15. Louise Holborn, Refugees: A Problem of Our Time: The Work of UNHCR 1951-72 (N.J.: Scarecrow Press, 1975).

16. Guy S. Goodwin-Gill, “The Language of Protection," International Journal of Refugee Law 1, no. 1 (1989), 10.

17. Ibid., 12.

18. Good offices referred to the office of UNHCR, which could be called upon on a discretionary basis to undertake special missions or to fill in gaps where the organization's mandate or statute did not apply.

19. Holborn, Refugees: A Problem of Our Time, 838.

20. Ibid., 440 .

21. Ibid., 294.

22. Ibid., 837 .

23. Statement of R. Rochefort of France, un Doc A/CONF.2/ SR.22 at 15, July 16, 1951, emphasis added; cited in Hathaway, "The Law of Refugee Status," 7.

24. Hathaway, "The Law of Refugee Status."

25. Hannah Arendt, The Origins of Totalitarianism (Cleveland/ New York: Meridian, 1958).

26. Hathaway, "The Law of Refugee Status," 93.

27. Ibid., 18 .

28. Ibid., 18-19; emphasis added.

29. As international law, the OAU Convention is legally binding and applicable to all signatory states. The oAs definition is based on the Cartegena Declaration, which, like the UN Declaration of Human Rights, is not binding. The ten states that signed the Cartegena Declaration in 1984 basically agreed to a definition of refugee similar to that enacted by the OAU, though not quite as comprehensive in terms of protection.

30. Ibid., 21.

31. The Convention on the Rights of the Child, the Convention against Torture, as well as the Declaration of Human Rights and the two international covenants, are also relevant instruments.

32. Hathaway, "The Law of Refugee Status," 26.

33. The Economist, "Get Out, Maybe," reprinted in the Globe and Mail, February 20, 1996.

34. Convention refugees, as noted, are those defined in law under the 1951 Convention and 1967 Protocol.

35. The source of this information is an e-mail transcript in response to request for clarification of UNHCR's interpretation of these terms in Kenya, June 12, 1996.

36. Mandate refugees do not meet the eligibility criteria of the Convention definition, yet are designed as in need of protection by UNHCR on the basis of its mandate, as outlined in the statute. Some countries may recognize their protection needs and designate their status as mandate refugees; some may not. I thank Viktor Nylund for his comprehensive tutorials in making this clear to me.

37. Francis M. Deng, "The International Protection of the Internally Displaced," International Journal of Refugee Law (summer 1995): 82 .

38. Articles 13.2 and 14 of the Un Declaration outline these rights. Article 15 states, "(1) Everyone has the right to a nationality; (2) No one shall be arbitrarily deprived of his [sic] nationality nor denied the right to change his [sic] nationality." See Annex II. 3 in UnHCR, The State of the World's Refugees: The Challenge of Protection (New York: Penguin, 1993).

39. Interview, senior manager, UNHCR, Geneva, October 18, 1994.

40. Aristide Zolberg, "Migrants and Refugees: A Historical Perspective," Refugees 91 (1992): 37.

41. Hathaway, "The Law of Refugee Status."

42. This impetus resonates with Canadian immigration law that became exclusionary only in the late 1870 s and early 1880 os.

43. Holborn, Refugees: A Problem of Our Time, 153.

44. Guy Goodwin-Gill cited in James Hathaway, "Reconceiving Refugee Law as Human Rights Protection," Journal of Refugee Studies 4, no. 2 (1991): 116. See also Jennifer Hyndman, Managing Displacement: Refugees and the Politics of Humanitarianism (Minneapolis: University of Minnesota Press, 2000).

45. Arendt, The Origins of Totalitarianism, 288.

46. Ibid., 286, 296.

47. J. Hyndman, "International Responses to Human Displacement: Neo-liberalism and Post-Cold War Geopolitics," Refuge 15, no. 3 (June 1996), 5-9.

48. J. Boutwell and M. T. Klare. "A Scourge of Small Arms," Scientific American (June 2000): 51.

49. Comparing both per capita GNP contributions and total contributions over the decade, the us Committee for Refugees $(1992,1995,2000)$ documents a steady climb in donations from countries in the North. For example, the us contributed $\$ 1.10$ per capita or $\$ 277.73$ million total in 1991; $\$ 1.53$ per capita or $\$ 397.74$ million in 1994 ; and $\$ 1.63$ per capita or $\$ 444.9$ million in 1999. Norway, as the most generous non-G7 country, donated $\$ 11.28$ per capita or $\$ 48.51$ million in 1991; $\$ 13.53$ per capita or $\$ 58.2$ million in 1994 ; and $\$ 15.62$ per capita or $\$ 70.3$ million in 1999; see us Committee for Refugees, 
World Refugee Survey, 2000 (Washington, DC: Immigration and Refugee Service of America, 1992, 1995, 2000).

50. Barutciski, "Confusion about UnHCR's Role," 2. As of January 1, 2001, UNHCR has a staff of 5000; see Mike Crawley, "UN Refugee Agency Turns 50," Globe and Mail, January 1, 2001.

51. UnHCR, The State of the World's Refugees: In Search of Solutions (Oxford/NY: Oxford University Press, 1995), 255.

52. Crawley, "Un Refugee Agency Turns 50."

53. Barutciski, "Confusion about unHCR's Role," 3.

54. Rosemary Rogers \& Emily Copeland, Forced Migration: Policy Issues in the Post-Cold War World (Massachusetts: Tufts University, 1993).

Jennifer Hyndman teaches in the Geography Department at Simon Fraser University. Her first book, Managing Displacement: Refugees and the Politics of Humanitarianism, provides an analysis of UNHCR in more depth. She is co-editing a volume of feminist research on gender politics in conflict zones, with Wenona Giles at York University.

(C) Jennifer Hyndman, 2001. This open-access work is licensed under a Creative Commons Attribution-NonCommercial 4.0 International License, which permits use, reproduction and distribution in any medium for non-commercial purposes, provided the original author(s) are credited and the original publication in Refuge: Canada's Journal on Refugees is cited. 